\title{
Refugiados LGBTI no Brasil
}

\author{
Fernanda Martinelli Sobreira*
}

\section{Introdução}

Um importante cenário no contexto internacional contemporâneo é o deslocamento de indivíduos de maneira forçada. Alguns seres humanos são levados a fugir de seus países por serem perseguidos devido às questões políticas, religiosas, militares, étnicas, de nacionalidade e por pertencerem a determinados grupos sociais específicos que são discriminados. Dessa maneira, indivíduos são obrigados a sair de seus países por sofrerem ameaças violentas e até mortes.

Nesse sentido, em algumas localidades do mundo, os indivíduos que pertencem a grupos sociais específicos, como os $\mathrm{LGBTI}^{1}$ correm risco de vida e são perseguidos muitas vezes pelo Estado, por grupos e por alguns indivíduos da sociedade civil. Isso acontece com maior intensidade nos países onde ser homossexual é crime, podendo levar até a pena de morte. Muitos deles chegam ao Brasil, país internacionalmente reconhecido como acolhedor, a fim de solicitar refúgio, com a ideia de que encontrarão uma vida digna e de respeito aos direitos humanos. Porém, quando chegam aqui encontram obstáculos para se integrarem à sociedade brasileira, como a dificuldade de aprendizado da língua portuguesa, a cultura, o mercado de trabalho, o acesso à educação, além de sofrerem discriminação e intolerância.

Conforme dados do ACNUR (2015), atualmente (2015) há 8.400 refugiados residentes no Brasil $^{2}$. Dentre eles, 18 foram reconhecidos por terem sido perseguidos ou sofrerem fundado temor de perseguição devido à própria orientação sexual ou identidade de gênero; e são 23 os solicitantes, com base neste critério, que estão pendentes de análise.

\section{I - A Convenção Relativa ao Estatuto dos Refugiados e os Direitos Humanos}

Após as duas Grandes Guerras, o mundo estava exausto de tantas destruições, mortes, genocídios e guerras. Dessa maneira, em 1945, foi criada a Organização das Nações Unidas (ONU), cujo objetivo era impedir a ocorrência

\footnotetext{
* Graduada em Relações Internacionais pela Faculdade de Ciências Sociais/PUC-SP. Este artigo é resultado do trabalho de conclusão de curso em Relações Internacionais, sob orientação da professora Dra. Dulce Maria Tourinho Baptista.
} 
de guerras, o que representava um sentimento de esperança para indivíduos e nações. Diante desse cenário desumano, horripilante e desprezível, um esforço mundial foi necessário para que houvesse a reconstrução dos direitos humanos, como modelo da ordem internacional contemporânea.

Assim, em 1948 foi promulgada a Declaração Universal dos Direitos Humanos (DUDH), assinada pelo Brasil no mesmo ano, cujo objetivo era indicar uma ordem pública internacional baseada no respeito à dignidade humana, através da consagração de valores básicos universais. Nesse sentido, evidencia-se a preocupação de sistematizar normas internacionais acerca dos direitos das minorias, conforme analisado a seguir em relação aos refugiados (PIOVESAN, 2012).

A primeira vez em que houve certa discussão sobre os indivíduos que buscavam residência em outro país, depois de fugirem de seu Estado de origem, ocorreu após a criação da Liga das Nações, em 1919. Em 1921, depois da Revolução Comunista de 1917 na Rússia e o esfacelamento do Império Turco Otomano, discutia-se como a comunidade internacional poderia dar um tratamento adequado aos refugiados russos, os quais saíram da Rússia e não conseguiam mais voltar, por terem sidos desnacionalizados. Criou-se, então, o Alto Comissariado para Refugiados, para tratar especificamente dessa situação. Porém, evidenciou-se que não havia apenas russos, mas também armênios refugiados na Grécia. Assim, decidiu-se que o Alto Comissariado seria voltado para todas as nacionalidades e para qualquer questão relacionada aos refugiados.

Com o surgimento de deslocados forçados pelo mundo, a Assembleia Geral da ONU de 1950 convocou uma conferência para o desenvolvimento de uma Convenção em Genebra, a fim de se dar um status legal aos refugiados. Dessa maneira, em 1950, foi criado o Alto Comissariado das Nações Unidas para os Refugiados (ACNUR), com os seguintes objetivos: proteger e ajudar as vítimas de perseguição, de violência, de intolerância e buscar soluções para que essas pessoas possam reconstruir suas vidas em um ambiente normal. E em 1951 foi adotada a Convenção Relativa ao Estatuto dos Refugiados.

No artigo 10 da Convenção, define-se que o termo "refugiado" deve ser aplicado a qualquer indivíduo

que, em consequência dos acontecimentos ocorridos antes de 1 o de janeiro de 1951 e temendo ser perseguido por motivos de raça, religião, nacionalidade, grupo social ou opiniões políticas, se encontra fora do país de sua nacionalidade e que não pode ou, em virtude desse temor, não quer valer-se da proteção desse país, ou que, se não tem nacionalidade e se encontra fora do país no qual tinha sua residência habitual em consequência de tais acontecimentos, não pode ou, devido ao referido temor, não quer voltar a ele (ACNUR: 1951, p. 2). 
Segundo o ACNUR, apesar da Convenção ser extremamente relevante, o documento era só aplicável ao fluxo de refugiados ocorrido antes de 1951, aos acontecimentos ocorridos na Europa, e não incluía refugiados de outros continentes. Com a emergência de perseguições e conflitos no mundo, foi necessário colocar os refugiados pós 1951 sob proteção da Convenção. Assim, foi criado o Protocolo Adicional à Convenção sobre Refugiados em 1967. Com a ratificação deste, os países se comprometeram a receber refugiados de qualquer época e de qualquer lugar. Ambos os documentos asseguram que qualquer indivíduo tem o direito de procurar refúgio em outro país.

A Convenção de 1951 foi ratificada e promulgada internamente pelo Brasil, em 1961. Já o Protocolo de 1967 foi promulgado internamente em 1972. Porém, na época, o Brasil só aceitava refugiados de origem europeia. Com o aumento da demanda de refugiados do mundo todo, passou a ocorrer pressões das entidades humanitárias e do ACNUR junto ao governo brasileiro e, em 1989, foi aceita a possibilidade para que indivíduos de qualquer país pudessem ser reconhecidos como refugiados no Brasil (ACNUR, 2012).

Em 1969, foi aprovada a Convenção da Organização da Unidade Africana, atualmente conhecida como União Africana, sobre refugiados. Essa Convenção reconhece que grupos paraestatais também causam perseguição, passandose a considerar um refugiado aquele que, por viver em um cenário de graves violações de direitos humanos, é obrigado a buscar refúgio em outro Estado. Essa definição foi admitida, em 1984, pela Declaração de Cartagena.

Nesse sentido, o ACNUR foi ratificado como a instituição internacional que promove instrumentos legais para a proteção dos refugiados, inspecionando a aplicação da Convenção e/ou Protocolo. Quando os Estados ratificam estes, mostram que aceitam cooperar com o ACNUR no desenvolvimento das funções. No Brasil, o ACNUR se instalou em 1977, a fim de implementar os acordos internacionais e também incentivar a criação de uma lei brasileira específica destinada aos refugiados. Trata-se da Lei № 9.474/97.

\section{II - A Legislação Brasileira e os Refugiados}

O Estado brasileiro define o refugiado de acordo com o que prevê a Convenção de 1951. E com a Lei № 9.474/97, já citada anteriormente, foi criado o Comitê Nacional para os Refugiados (CONARE), órgão de deliberação coletiva vinculado ao Ministério da Justiça, o qual assume, em nome do Estado Brasileiro, o procedimento de análise da solicitação de refúgio, além de apoio e proteção aos que forem considerados refugiados ${ }^{3}$ (ACNUR, 2012, p. 31).

\section{III - Refugiados e causas da perseguição}

São diversas as causas de perseguição. De acordo com o ACNUR (1951), uma delas é a "raça" que deve ser interpretada como todos os tipos de grupos étnicos, segundo o senso comum, considerados como "raça." Também podem 
ser considerados os grupos sociais de origem comum, que formam uma minoria dentro de uma extensa população.

Outra causa de perseguição se dá por motivos religiosos; refere-se a discriminar um grupo que compartilha crenças, tradições comuns e práticas religiosas específicas. A perseguição pode ocorrer de variadas formas, como: imposição de medidas discriminatórias sobre indivíduos por pertencerem a uma comunidade religiosa ou por praticarem a própria religião; ou, proibição de praticar um culto em espaço privado ou público, da educação religiosa ou de fazer parte de uma comunidade religiosa.

Outra dimensão da perseguição está na nacionalidade que não deve ser interpretada apenas como o vínculo que une um indivíduo a um Estado. Pode se referir também ao pertencimento a um grupo étnico ou linguístico, ou seja, a perseguição contra grupos étnicos, linguísticos e culturais marginalizados no conjunto da população, também pode ser entendida como perseguição baseada na nacionalidade. A perseguição pode ocorrer através de diversas ações contra uma minoria nacional. Situações assim podem existir quando dois ou mais grupos nacionais estão dentro de um mesmo Estado.

A diversidade de opinião política faz referência às ideias não toleradas pelas autoridades, como a opinião crítica em relação às políticas governamentais ou as opiniões individuais. Muitas vezes, as autoridades podem considerar que um indivíduo possui determinada opinião política particular, mesmo que de fato, o indivíduo não defenda nenhuma opinião.

Já o pertencimento a um grupo social específico refere-se às pessoas cujo estilo de vida, origem e condição social são parecidos e não têm reconhecimento na sociedade nacional. São as pessoas que compartilham a mesma história, hábitos e estatutos sociais. A origem da perseguição pode ocorrer pelo fato do indivíduo fazer parte desse grupo específico, que pode ser considerado um obstáculo à política do governo. Esse grupo social específico pode ser aplicado, a depender do contexto, às famílias capitalistas, aos negociantes, aos membros de forças militares, aos proprietários de terras, aos bissexuais, transgêneros, homossexuais, os quais são alvos de discriminação, sobretudo em países com cultura sexista.

Para exemplificar o caso, segundo o ACNUR (2009), relatam-se dois solicitantes de refúgio que eram de uma região da Colômbia com presença paramilitar, onde se praticava a "limpeza social", isto é, assassinatos seletivos que tinham como alvo pessoas consideradas nocivas à sociedade, como viciados em drogas, prostitutas, ladrões, homossexuais. Os solicitantes estavam sempre juntos e eram vistos como homossexuais pelos grupos armados, que os ameaçavam e agrediam para que ingressassem nos grupos armados a fim de "tomar armas e virar homens." (ACNUR, 2009, p. 53). A ocorrência de assassinatos homofóbicos em determinado país é o motivo pela existência de um fundado temor dos solicitantes.

Os casos de indivíduos que solicitam refúgio por sua orientação sexual são, muitas vezes, ocultados no Brasil, primeiro porque, geralmente, esse indivíduo viveu grande parte de sua vida em um país onde não ser heterossexual 
é considerado doença, é crime para parte da população e pelo Estado. Notase que esse indivíduo passou muitos anos de sua vida com seus sentimentos reprimidos, sem ser o que ele é, sem poder se expressar naturalmente, com a equivocada ideia de que a própria sexualidade é algo errado e não natural dos seres humanos.

Assim, após chegar ao Brasil, é difícil para esse sujeito "sair do armário" e afirmar a uma autoridade brasileira ou às pessoas, que está no país devido à sua orientação sexual. Além disso, o solicitante ocultará a sua sexualidade aos outros refugiados, por estes terem vivido grande parte da vida em países de intolerância. Nesse sentido, é necessário entender mais sobre a situação de vida dos LGBTI em diversas partes do mundo.

\section{IV - A Situação dos Indivíduos LGBTI no Mundo}

Segundo dados da International Lesbian Gay Bisexual Trans and Intersex Association - ILGA (2014), dos $195^{4}$ países do mundo, em 78 deles as relações homossexuais são ilegais 5 . Dentre esses 78 , em sete países, como Arábia Saudita, lêmen, Irã, Mauritânia, Sudão, e em algumas áreas da Nigéria e da Somália, ser homossexual é proibido, o que leva à condenação a morte. E ainda há outros quatro países em que não se sabe claramente se o código da Sharia ${ }^{6}$ está sendo implementado, os quais são: Brunei, Iraque, Paquistão e Qatar.

Na Mauritânia, o código penal de 1984, afirma que: "Qualquer muçulmano adulto que cometa um ato indecente ou um ato contra a natureza com um indivíduo de seu sexo, fica sujeito à pena de morte por apedrejamento público." (ILGA, 2014, p. 39)

No Sudão, o código penal de 1991, pune a sodomia7:

Quem quer que tenha cometido sodomia será punido com o castigo de 100 chibatadas e ele será responsável por cinco anos de prisão. Se o acusado for considerado culpado pela segunda vez, ele será punido com 100 chibatadas e será preso por um período que não pode exceder cinco anos. Se o acusado for considerado culpado pela terceira vez, ele será punido com morte ou prisão perpétua (ILGA, 2014, p. 46).

De acordo com Arno Schmitt e Jehoeda Sofer (1992, apud ILGA, 2014, p. 62), a proibição

não está codificada no direito penal na Arábia Saudita. Ao invés disso, o país aplica estritas leis baseadas na Sharia. De acordo com a interpretação, a sodomia é criminalizada. Para um homem casado a penalidade é morte por apedrejamento, enquanto a pena para um homem solteiro 
é de 100 chicotadas (...). Para um não muçulmano que comete sodomia com um muçulmano, a penalidade é morte por apedrejamento. Além disso, toda relação sexual fora do casamento é ilegal na Arábia Saudita de acordo com a lei da Sharia, incluindo relações sexuais entre mulheres (ILGA, 2014, p. 62).

No lêmen, o código penal de 1994 afirma que: "a homossexualidade entre homens é definida como penetração dentro do ânus. Homens não casados serão punidos com 100 chibatadas ou o máximo de um ano de prisão, homens casados serão punidos com morte por apedrejamento." Em outro artigo é tratado que "o lesbianismo é a relação sexual entre uma mulher e outra. Qualquer uma envolvida neste ato com outra será punida com pena de prisão por um período não superior a três anos. Se o ato acontece sob coação, o tempo na prisão pode ser expandido para sete anos" (ILGA, 2014, p. 66).

Já o código penal do Irã, de 1991, explicita as punições para sodomia:

A punição para sodomia é a morte. O juiz da Sharia é quem decide sobre qual a forma de realizar a matança (...). Se o sujeito adulto e de boa mente tem relações sexuais com um menor, o executor será morto e o passivo será sujeito a 74 chibatadas se não sofreu coação. Se um menor tem relação sexual com outro menor, ambos estão sujeitos a 74 chibatadas, a menos que um deles estava sob coação (ILGA, 2014, p. 58).

Também são citadas as punições para o lesbianismo:

Lesbianismo é a homossexualidade de mulheres por órgãos genitais. A punição para o lesbianismo é de 100 chicotadas por cada uma das partes (...). Se o ato de lesbianismo for repetido (...) a sentença de morte será aplicada na quarta vez (ILGA, 2014, p. 58).

Segundo a ILGA (2014), em variados Estados do norte da Nigéria têm sido adotadas as leis da Sharia, que criminaliza as relações sexuais entre pessoas do mesmo sexo. A penalidade máxima para atos sexuais entre homens é de condenação à morte, enquanto para mulheres é de chicotadas ou prisão. Em 2013, uma lei de proibição de casamento de mesmo sexo foi aprovada pelo Cogresso e assinada pelo presidente em janeiro de 2014. Segundo a lei, "um contrato de casamento ou união civil entre pessoas do mesmo sexo é proibido na Nigéria." (ILGA, 2014, p. 42). 
Já na Somália, de acordo com a ILGA (2014), a situação política tem se complicado. Uma área no norte do país declarou-se independente, mas ainda aplica o código penal que era imposto pelo ditador Mohamed Siad Barre até 1991. Recentemente, houve casos de pessoas condenadas à morte no país, como o de um casal de lésbicas que foram condenadas à morte por um juiz (ASYLUM LAW ORG, 2014), ou o caso de um jovem gay de 18 anos, o qual, em 2013, foi julgado e condenado por um juiz. Diante de uma multidão de aldeões, o jovem foi apedrejado até ser morto (BENNETT-SMITH, 2013).

Em fevereiro de 2014, de acordo com a ILGA (2014), o presidente de Uganda, Yoweri Museveni, sancionou a lei contra a homossexualidade, a qual foi aprovada pelo parlamento no final de 2013. Essa lei estabelece a pena de prisão perpétua para homossexualidade praticada mais de uma vez. Segundo o jornal BBC (2014), quando essa nova lei foi aprovada, vários doadores internacionais como os EUA, Dinamarca, Noruega, Suécia e Holanda, cortaram a ajuda para Uganda, com restrições de viagem aos funcionários ugandeses envolvidos em graves violações dos direitos humanos e cortes de fundos de programas com as autoridades ugandesas. Com essas sanções, em agosto de 2014, o Tribunal Constitucional, anulou a legislação contra os gays assinada em fevereiro de 2014. O governo de Uganda alegou que a decisão seria para mostrar aos doadores ocidentais que a democracia de Uganda está funcionando bem e que eles deveriam repor qualquer ajuda que foi cortada (BBC, 2013).

Em todos esses países, é evidenciada uma barbárie e intolerância em relação aos indivíduos LGBTI. Uma intolerância preexistente, como defende Eco (2000), com linchamentos, prisões perpétuas, apedrejamentos até a morte. Nesses casos, o ódio e a intolerância são sustentados pelos Estados (Ricceur, 2000). Outro país onde se está crescendo o ódio e a intolerância sustentada pelo Estado em relação aos homossexuais é a Rússia, onde a homossexualidade foi legalizada há 21 anos e os gays estão sendo literalmente caçados por grupos homofóbicos, sofrendo violência física e psicológica, espancamentos, torturas, estupros, ameaças e até morte. Em 2014, o Parlamento do país iniciou a propaganda de uma lei que queria proibir todos os relacionamentos não tradicionais. A partir dessas atitudes do Estado, junto com a propaganda da Igreja Ortodoxa contra os gays, grupos vigilantes conservadores e violentos estão atacando gays e lésbicas no país, com a justificativa de que os homossexuais são pedófilos. ${ }^{8}$

É contrário aos Direitos Humanos evidenciar esses tipos de ações que ocorrem em variados Estados, sem falar nas inúmeras outras histórias de intolerância em relação aos indivíduos LGBTI que são ocultadas. Estes são vistos como "os outros", que não sentem e não pensam como os que praticam os atos violentos de intolerância e ódio, os quais se consideram a essência da humanidade e da civilização. 


\section{V - Os Refugiados LGBTI e a intolerância}

Tanto os refugiados quanto os indivíduos LGBTI são vítimas de intolerância, discriminação e preconceito na sociedade brasileira e em diversas partes do mundo. Quando um brasileiro escuta a palavra "refugiado", ele tende a pensar que o refugiado é um criminoso que teve que fugir de seu país e pediu asilo ao Brasil. E quando escuta que um indivíduo é homossexual, esse brasileiro, se for preconceituoso, tratará essa pessoa de maneira diferente, com um certo distanciamento, talvez com uma "risadinha sarcástica" e um olhar diferente, com a equivocada ideia de que esse "homossexual" poderá "agarrá-lo" e que sente algum tipo de atração sexual e afetiva por ele". Evidencia-se nesta sociedade, ainda muito conservadora, esse tipo de preconceito arraigado em várias famílias, indivíduos, instituições, entre outros.

Assim sendo, quando se fala em refugiado LGBTI, a intolerância é maior, pois além do indivíduo sofrer discriminação e xenofobia por ser refugiado, poderá sofrer preconceito por sua orientação sexual. Existem casos no Brasil de solicitantes de refúgio por causa da orientação sexual, mas eles encontram muita dificuldade, pois a homossexualidade, embora não proibida por lei, é ainda tabu neste país. Segundo Sharalyn Jordan e Chris Morrissey (2013), o Brasil realiza a maior parada do orgulho gay do mundo, mas, ao mesmo tempo, tem a taxa mais alta do mundo de assassinatos homofóbicos e transfóbicos.

Os estudos de caso apresentados a seguir constatam essa realidade. São casos verídicos, porém foram utilizados nomes fictícios. Esses refugiados relatam a dificuldade em enfrentar a discriminação e o preconceito tanto no país de origem, quanto no Brasil e a dificuldade de viverem da maneira como realmente são.

O primeiro caso, de uma mulher do Irã, é apresentado no estudo de Larissa Leite (2013):

Neda, hoje com trinta anos, deixou o seu país no Oriente Médio, após uma sequência de censuras por suas formas de expressão. A experiência de haver estudado em colégio internacional e de ter conhecido outros países impulsionava-a a desejar pequenas liberdades que frustravam as expectativas sobre o comportamento de uma jovem e violavam as normas legais impostas pelas autoridades. Na adolescência, Neda desejava poder brincar, se relacionar e se expressar com seus amigos sem se preocupar com as fiscalizações policiais ou a censura social. Queria vestir-se sem véus ou saias longas. Mas não era possível: a separação entre homens e mulheres era sempre intransigente nos espaços públicos ou mesmo em festas privadas. Durante o período de escola, Neda teve um namorado, mas eles perderam contato quando ele se 
formou. Depois de um tempo, ela acompanhou o pai em uma viagem de negócios, por alguns meses, e conheceu uma outra jovem estrangeira. A relação de carinho teve início como amizade e depois se aprofundou. A então namorada chegou a visitar Neda no Irã, sendo que tudo foi aceito com naturalidade por sua família. "Os pais sabem de tudo", conta ela. Após este relacionamento, Neda foi presa por participar de uma festa homossexual. Embora permitidas, as festas privadas exclusivamente entre homens ou entre mulheres podem ser tomadas como "suspeitas" para a polícia - já que o homossexualismo é crime. Tempos depois, Neda recebeu uma advertência (que resultou na sua demissão) por haver abraçado sua segunda namorada em um local público. Finalmente, teve seu carro apreendido, sob a alegação de não estar vestindo corretamente o véu islâmico e ter maquiagem excessiva. Com o apoio da família, ela resolveu buscar o Brasil, e aqui foi reconhecida como refugiada, por perseguição decorrente de sua orientação sexual. Hoje, trabalha e sente-se feliz, convivendo com amigos e amigas, como sempre desejou desde a adolescência. (LEITE, 2013, p. 1)

O segundo caso é de um homem do Paquistão, também estudado por Leite (2013):

"Eu sou humano. Nasci num país onde pessoas pensam que homossexualidade é uma doença." Ali, não compreendia a atração que sentia por homens durante a adolescência, mas testemunhava o tratamento dado aos homossexuais em seu país - o Paquistão. Ele lembra que "duas mulheres se casaram e fugiram. Elas foram encontradas e presas. Depois, foram tratadas como loucas e internadas para tratamento psiquiátrico por suas famílias". Na faculdade, porém, Ali soube da existência de "websites para gays" e passou a acompanhá-los. Em uma rede social, foi convidado para um encontro, mas ficou paralisado quando percebeu que quem o convidava era um vizinho seu, casado e com filhos. Ali nada respondeu. Depois, encontrou-se com um rapaz da Arábia Saudita, mas não estabeleceu nenhuma relação efetiva. Eram quase nulas as oportunidades para desenvolver sua sexualidade. Temia pela sua reputação e a de sua família. "Eu ficava com medo até de abrir os sites", diz ele. Resolveu que precisava sair do país, para buscar um espaço onde pudesse se expressar e crescer, não importando o que custasse. Foi, então, que veio ao Brasil - e foi somente aqui que conheceu a possibilidade de pedir formalmente o refúgio. Foi também aqui que ele 
pôde buscar sua identidade pessoal e a compreensão sobre a sua orientação sexual. Teve alguns relacionamentos e experiências. Hoje, trabalha em um supermercado e vive em uma casa de acolhida pública. Aprendeu a fazer bijuterias artesanais e acalenta o sonho de escrever uma novela e filmar documentários sobre o Brasil (LEITE, 2013, p. 1).

O terceiro caso do estudo de Leite (2013) é de um homem da Nigéria:

Ikenna nasceu em uma pequena vila da Nigéria. É o filho do meio de sete irmãos. Viveu com os pais até os 14 anos, quando partiu para trabalhar em outras cidades. Aprendeu muitos ofícios e seguiu estudando. "Na Nigéria não há clubes gays e as pessoas não mudam o seu jeito de ser", conta. Os relacionamentos de Ikenna com outros rapazes, então, começaram na escola ou através de gestos muito sutis em discotecas, no início da juventude. Era preciso ser cuidadoso, porque se fosse notado ou abordasse alguém erroneamente, poderia sofrer muitos tipos de censura. Ikenna, de fato, sofreu algumas vezes. Era comum ser ofendido nos locais onde sua sexualidade era revelada. Tinha dificuldades para conseguir trabalho e, algumas vezes, chegou a ser agredido fisicamente. Ir à polícia não era uma alternativa. "Na polícia, uma palavra é tudo...". Sua mãe conhecia a sua orientação sexual e o defendia incansavelmente na comunidade. Sempre que estava com ele, ela o levava a cultos religiosos, querendo ajudálo. Mas um dia, sem qualquer sintoma prévio, ela faleceu. Muitos dos seus familiares e vizinhos culparam Ikenna e a sua sexualidade pela morte da mãe. Eles ameaçaram matá-lo e ele precisou fugir. Aos 36 anos, Ikenna tem uma pequena loja de acessórios eletrônicos no Brasil e vive em segurança. Mas não se sente feliz. "Sem a família, falta um pedaço", diz. Ainda está confuso sobre tudo o que lhe aconteceu. Aqui, não estabeleceu nenhum relacionamento afetivo, tendo poucos amigos - todos brasileiros. Ele conta que não confraterniza com compatriotas seus e que se mantém afastado das comunidades africanas por medo. Busca manter-se em paz frequentando cultos cristãos, em memória de sua mãe (LEITE, 2013, p. 2).

O último caso relatado e divulgado pela autora citada é de um homem da Colômbia:

"Sou gay, soropositivo e refugiado". É assim que o colombiano Ramirez começa a contar sua história, que ainda traria o desafio do câncer. Militar de carreira, 
falante de quatro idiomas estrangeiros e graduado em duas faculdades, Ramirez mantinha um relacionamento homossexual estável há oito anos, quando seu companheiro veio a falecer em decorrência do HIV. Os pais dele estimularam Ramirez a reclamar pelo direito à pensão e à sucessão. Tendo feito isso, Ramirez teve a sua orientação sexual conhecida pelas Forças Armadas. Embora alguns de seus superiores o tenham apoiado, ele virou motivo de piada geral. "Maricón, nené" e outras tantas expressões pejorativas era o que ouvia entre as tropas. Mas o pior seria a pressão que viria a sofrer na sequência e que levaria à sua exoneração, por suposta insubordinação. Iniciava-se um infindo processo judicial. De baixa do exército, Ramirez decidiu pelo trabalho ativista em prol da prevenção ao contágio e do tratamento de pessoas portadoras do vírus HIV. A discriminação por sua orientação sexual seguia naquele ambiente, marcado pela rivalidade entre grupos paramilitares e a guerrilha colombiana. Trabalhando em pequenos vilarejos do interior da Colômbia, testemunhou crueldades que procurou denunciar. Mas recebeu da própria polícia recomendações para se calar. Ainda assim, resistiu em continuar o trabalho. Um dia, o posto médico da organização para a qual Ramirez trabalhava atendeu a companheira de um guerrilheiro, o que foi a gota d'água: o grupo paramilitar que disputava o controle da região passou a perseguir definitivamente Ramirez, numa sequência de ameaças e atentados para os quais a polícia fechou os olhos. Já não foi possível resistir. Ramirez buscou refúgio inicialmente na Argentina e, depois, no Brasil. A presença de ex-membros dos grupos armados colombianos era muito forte no país vizinho e Ramirez não se sentia em segurança. Aqui no Brasil, apesar de sua elevada qualificação profissional, teve muitas dificuldades ao buscar um emprego. "As pessoas pensam que refugiados são delinquentes ou que refugiado tem que trabalhar como pedreiro." E completa: "se o Brasil vivesse uma tragédia, também haveria refugiados brasileiros em outros lugares". Ele diz que nunca esconde o fato de ser homossexual e diz que há uma aceitação melhor a este fato no Brasil. Mas na sequência enfatiza que foi muito difícil obter um bom emprego (LEITE, 2013, p. 2).

O próximo caso apresentado refere-se a história de vida de um refugiado de Bangladesh, Partha Sarker, o qual aceitou ser entrevistado por mim, em maio de 2015, agregando dados a este artigo: 
Vim sozinho e fui mandando de um lado a outro pelos países da América do Sul, até chegar ao Brasil. Assim que cheguei, fui detido e levado para uma sala no aeroporto, onde fiquei, muitas vezes, sem comida ou sem acesso às necessidades básicas. Foi muito difícil solicitar refúgio. Tive que brigar com muitos ao longo do caminho até que eu consegui. Quando fiquei detido, entrei, secretamente, em contato com a Cáritas e a Missão Paz através de meu iPad (a Polícia Federal não sabia que eu o tinha comigo). Felizmente, eu tinha créditos no Skype e usei o Wi-Fi grátis para buscar ajuda de fora. Embora a Polícia Federal tentasse de tudo para me mandar para fora do país, eu resisti e não parti. Com a gentil ajuda do pessoal da Cáritas e da Missão Paz, meus dias detidos acabaram e, finalmente, fui solto depois de uma semana. Ouvi dizer que há pessoas que ficam presas durante meses. Infelizmente, a maioria dos brasileiros não sabe o significado de refugiado. As pessoas tendem a acreditar no que o programa "Cidade Alerta" transmite, uma enorme distorção da realidade. Há medos espalhados e desinformação que predomina na comunidade brasileira quando o assunto é aceitar os refugiados. Grande parte dos indivíduos nos considera como fabricantes de bombas ou como um terrorista fugitivo ou como alguém que tomará o trabalho de um brasileiro. Em relação ao motivo de eu estar aqui como refugiado, posso dizer que, se eu não tivesse saído do meu país, eu seria morto. Temendo os danos à minha vida, saí de Bangladesh. Resumidamente, depois de passar por uma purificação Islâmica para curar a minha orientação sexual, percebi que eu não tinha proteção nem do Estado e nem da sociedade. O processo de purificação incluía chicotadas, jejum forçado, afogamento simulado, intimidação, prisão forçada, entre outros. Tudo isso ocorria dentro de uma mesquita durante dias e, para dizer a verdade, eu até esqueci quanto tempo durou. Mesmo depois da minha suposta fuga (tive que brigar com três indivíduos para ganhar minha liberdade de situação de refém), o perigo presente e claro persistiu. Assim, escapei para o país vizinho e isso me ajudou a reduzir bastante a pressão que eu sentia sobre mim. Simplificando, tive que sair do meu país para que eu pudesse viver, pois as pessoas podem extorquir um homossexual, devido ao fato da homossexualidade ser um delito culpável na corte de Bangladesh, com a punição de 14 anos de prisão. Eu não poderia ficar com meu namorado devido ao medo e ao estigma social. Sempre pensei que havia algo errado comigo e sentia culpa. E isso afetou a minha habilidade de construir relações, depois de viver como um gay enrustido por tanto tempo. Lamentavelmente, não há proteção para pessoas como nós, nem da família e nem da polícia. Proteção é algo 
dentro da norma e a homossexualidade não é a norma, é uma doença e é indicada como uma ofensa ao Estado e, como pena máxima, a prisão perpétua.

Diante dos casos apresentados constata-se que esses indivíduos sofreram muito, passaram por traumas psicológicos inimagináveis, muitas vezes foram quase mortos e buscam, no Brasil, apenas uma maneira de recomeçar a vida. Apesar da existência da lei brasileira que exige que o governo dê assistência ao refugiado e das organizações que buscam ajudar o refugiado, como o ACNUR, a Caritas Arquidiocesana, a Casa do Migrante, a Missão Paz e as ONGs, ainda há muito preconceito em relação ao "outro" na sociedade brasileira. Nos casos dos refugiados $L G B T I$ relatados percebe-se a dificuldade de se obter um bom emprego, para que possam se manter e construir uma nova vida. Eles só desejam recomeçar, conseguir autonomia neste país e ter apoio das pessoas. Porém, nas entrevistas para acesso aos postos de trabalho, os empregos lhes são, muitas vezes, negados ${ }^{10}$, ainda mais se forem originários de países que têm passado por situações difíceis internamente, como Síria, Irã, República Democrática do Congo, Haiti, Bangladesh, Colômbia, Paquistão, entre outros. No entanto, imigrantes de países do Norte, como europeus, estadunidenses, canadenses são muito bem tratados pelos brasileiros, cuja hospitalidade é bem conhecida ao redor do mundo. Porém, quando são de países ao Sul do Equador, ou seja, países menos desenvolvidos economicamente, esses indivíduos sofrem preconceito, discriminação e intolerância, o que mostra o desrespeito aos direitos humanos da sociedade brasileira para com o refugiado.

Enquanto não houver mais respeito ao outro, com uma maior disseminação e visibilidade dos refugiados, dos LGBTI e dos refugiados LGBTI, serão presenciados ainda mais casos de refugiados discriminados e de homossexuais apanhando nas ruas, sem poderem viver tranquilamente como gostariam.. Enquanto não for difundido nas escolas, nas famílias, na mídia e em toda a sociedade a ideia da tolerância, de que é necessário aceitar de fato todas as pessoas como iguais e livres em direito e não apenas juridicamente como seres humanos, continuará ocorrendo essas desesperadoras violações dos direitos humanos. Conforme defendido por Héritier (2000), para que isso ocorra, é necessário uma tomada de consciência coletiva e individual, vontade política internacional e um sistema educacional que ensine a não odiar. Para isso, políticas públicas efetivas do governo são necessárias.

\section{Considerações Finais}

Após as leituras, análises, estudos exploratórios e estudos de caso feitos para esta pesquisa, conclui-se que, apesar do avanço dos direitos humanos e dos refugiados, existe ainda preconceito, intolerância e discriminação com mais ênfase ao refugiado LGBTI. Mesmo com a ratificação das convenções 
internacionais e com a Lei brasileira № 9.474/97, ainda há muito caminho para se percorrer, com o intuito de proteger e dar auxílio ao ser humano que está refugiado no Brasil, o qual não é criminoso. Na verdade, como vimos, são pessoas vitimadas em seus direitos. É muito difícil para essa pessoa deixar seu ambiente natural, sua pátria, laços sociais, família, amigos e amores para buscar recomeçar a vida neste país.

Quanto à homossexualidade, apesar de ser fato extremamente natural, que aparece no decorrer da história, em diferentes civilizações, o preconceito, a discriminação e a intolerância são percebidos no cotidiano, por meio de "risadinhas sarcásticas", olhares diferentes, agressões verbais e até com espancamentos e mortes planejadas por indivíduos, os quais se entendem como a "essência da civilização" e, assim, demonizam o "outro", com a crença de que possuem a verdade absoluta. Esse preconceito está arraigado em variadas famílias, indivíduos, escolas, governos, Igrejas, dentre outros setores da sociedade brasileira.

Por fim, os refugiados LGBTI sofrem intolerância, discriminação e preconceito muito maior, primeiro porque sofreram discriminação nos seus países de origem, segundo por toda a intolerância que encontrarão em sociedades conservadoras, onde ainda existem tabus. Políticas públicas para conscientização da população são extremamente necessárias, especialmente nas escolas, para que indivíduos LGBTI e os que estão refugiados no Brasil não sejam invisibilizados, mas tratados de maneira igual, como seres humanos portadores de direitos.

No Brasil e em outros lugares ao redor do mundo, há um esquecimento por grande parte dos indivíduos de que a base da sociedade é formada pelos próprios seres humanos, isto é, antes da formação de Estados, fronteiras, países e nacionalidades, existiam os indivíduos, os quais não são máquinas. São, na verdade, sujeitos dotados de sentimentos, que necessitam de carinho, amor, entendimento, relações afetivas e sociais. A exclusão, a marginalização e a intolerância trazem apenas consequências negativas para todos. Portanto, é necessário que haja mais respeito aos direitos entre os indivíduos, para se conseguir viver em um ambiente de paz, tolerância, entendimento, sem linchamentos, trazendo "o outro" para perto de si, para a inclusão social. Para isso, entretanto, são necessárias políticas públicas de conscientização e inclusão do "outro", incluso o refugiado LGBTI.

\section{Notas}

1 - Segundo o ACNUR - Alto Comissariado das Nações Unidas para Refugiados (2012), o termo LGBTI significa: "lésbicas, homens gays, bissexuais, transgêneros e intersexo". O primeiro refere-se a uma mulher cuja atração física e/ou emocional é direcionada a outras mulheres. $O$ termo "gay" é usado para um homem que possui uma atração física e/ou emocional por outros homens. Porém, esse termo pode ser utilizado tanto para homens, quanto para mulheres gays. Já o bissexual é o indivíduo que é fisicamente e/ou emocionalmente atraído por homens 
e por mulheres. O termo transgênero refere-se às pessoas cuja identidade de gênero e/ou expressão de gênero é diferente de seu sexo biológico. E o intersexo é a condição em que o indivíduo nasce com uma anatomia reprodutiva ou sexual e/ou com padrões cromossômicos que não se enquadram nas noções biológicas típicas de um homem ou uma mulher.

2 - Considerando que o país possui cerca de 200 milhões de pessoas, 8.400 refugiados é um grupo muito pequeno para o total de sua população. E é menor ainda frente aos 59,5 milhões de pessoas refugiadas no mundo (ACNUR, 2015).

3 - É interessante lembrar também que o refúgio não é concedido aos indivíduos que cometeram crimes de guerra, crimes contra a humanidade e contra a paz e que praticaram atos contrários aos princípios da ONU - Organização das Nações Unidas.

4 A ONU considera a existência de 193 países. Porém, se considerados o Vaticano e Taiwan, que a despeito de não ter a sua independência reconhecida pelo Estado Chinês, há um total de 195 países no mundo (Nota do Editor).

5 - De acordo com a ILGA (2014), os 78 países são: na África - Argélia, Angola, Botsuana, Burundi, Camarões, República Centro Africana, Comores, Egito, Eritreia, Etiópia, Gâmbia, Gana, Guiné, Quênia, Lesoto, Libéria, Líbia, Malauí, Mauritânia, Maurício, Marrocos, Moçambique, Namíbia, Nigéria, Senegal, Seichelles, Serra Leoa, Somália, Sudão do Sul, Sudão, Suazilândia, Tanzânia, Togo, Tunísia, Uganda, Zâmbia e Zimbábue; na Ásia - Afeganistão, Bangladesh, Butão, Brunei, Índia, Irã, Kuwait, Líbano, Malásia, Maldivas, Myanmar, Omã, Paquistão, Catar, Arábia Saudita, Cingapura, Sri Lanka, Síria, Turcomenistão, Emirados Árabes Unidos, Uzbequistão e lêmen; na América Latina e Caribe - Antígua e Barbuda, Barbados, Belize, Dominica, Granada, Guiana, Jamaica, São Cristóvão e Nevis, Santa Lúcia, São Vicente, Granadinas e Trinidad e Tobago; na Oceania: Kiribati, Nauru, Palau, Papua Nova Guiné, Samoa, Ilhas Salomão, Tonga e Tuvalu.

6 - A Sharia é um código de conduta baseado na religião islâmica, o qual inclui as regras que regem a sociedade islâmica, como por exemplo, o que é permitido e o que é proibido, os modos de culto, a pena de morte, entre outros.

7 - Sodomia é a relação sexual anal entre pessoas do sexo masculino ou entre um homem e uma mulher.

8 - De acordo com o documentário "Hunted: the war against gays in Russia", produzido pela HBO e lançado no Brasil em outubro de 2014.

9 - Ver o documentário "Meninos de Rosa, Meninas de Azul (Homofobia e Bullying Homofóbico)." Produtores: Vinicius Kairalla, Danilo César Francisco. Faculdades Integradas Alcântara Machado - FIAM, Jornalismo, II semestre, 2012.

10 - Segundo o documentário “Refugiados", produzido pela Casa do Migrante, em 2010.

\section{Referências:}

ACNUR. Cadernos de Debates Refúgio, Migrações e Cidadania. Brasília: Instituto Migrações e Direitos Humanos, 2009.

. Convenção Relativa ao Estatuto dos Refugiados. 1951. Disponível em: http://www. acnur.org/t3/fileadmin/scripts/doc.php?file=t3/fileadmin/Documentos/portugues/BDL/ Convencao_relativa_ao_Estatuto_dos_Refugiados Acesso em: 15 de junho de 2015. 
. Declaração de Cartagena sobre Refugiados. Disponível em: http://www.acnur.org/ cartagena30/pt-br/declaracao-de-cartagena-sobre-refugiados/ Acesso em: 15 de junho de 2015.

Diretrizes sobre Proteção Internacional N.09: Solicitações de Refúgio baseadas na Orientação Sexual e/ou Identidade de Gênero no contexto do Artigo 1A(2) da Convenção de 1951 e/ou Protocolo de 1967 relativo ao Estatuto dos Refugiados. Outubro de 2012. Disponível em:

http://www.acnur.org/t3/portugues/recursos/documentos/?tx_danpdocumentdirs_ pi $2 \% 5$ B pointer\%5D=0\&tx_danpdocumentdirs_pi $2 \% 5 B$ mode $\% 5 D=1 \&$ tx _ danpdocumentdirs_pi2\%5Bsort\%5D=doctitle,sorting,uid

Acesso em: 30 de outubro de 2014.

Perseguidos por sua orientação sexual, refugiados LGBTI conseguem proteção no Brasil. Março de 2015. Disponível em: http://www.acnur.org/t3/portugues/noticias/ noticia/perseguidos-por-sua-orientacao-sexual-refugiados-Igbti-conseguem-protecaono-brasil/

Acesso em 15 de junho de 2015.

ASYLUM LAW ORG. Somali lesbians sentenced to death. Disponível em: http://www. asylumlaw.org/docs/sexualminorities/Somaila023201.pdf Acesso em: 23 de outubro de 2014.

BBC. Uganda court annuls anti-homosexuality law. Agosto de 2014. Disponível em: http:// www.bbc.com/news/world-africa-28605400 Acesso em: 15 de junho de 2015.

ECO, U. Definições léxicas. In: ACADEMIA UNIVERSAL DAS CULTURAS. A Intolerância. Rio de Janeiro: Bertrand Brasil, 2000, p. 15-19.

HÉRITIER, F. O Eu, o Outro e a intolerância. In: ACADEMIA UNIVERSAL DAS CULTURAS. $A$ Intolerância. Rio de Janeiro: Bertrand Brasil, 2000, p. 24-27.

BENNETT-SMITH, M. Gay Teen Allegedly Stoned To Death In Somalia For Sodomy. Março de 2013. Disponível em: http://www.huffingtonpost.com/2013/03/21/gay-teen-stonedsomalia-sodomy_n_2916655.html Acesso em: 15 de junho de 2015.

ILGA - INTERNATIONAL LESBIAN GAY BISEXUAL TRANS AND INTERSEX ASSOCIATION; ITABORAHY, L. P.; ZHU, J. State-Sponsored Homophobia. A world survey of laws: Criminalisation, protection and recognition of same-sex love. Disponível em: http://old. ilga.org/Statehomophobia/ILGA_SSHR_2014_Eng.pdf Acesso em: 20 de outubro de 2014.

JACMED, L. Refugiados. (Documentário). São Paulo: Casa do Migrante/Missão Paz, 2010.

JORDAN, S.; MORRISEY, C. ¿Por qué motivos? Solicitudes de asilo de LGBT en Canadá. Revista Migraziones Forzadas, Oxford, no 42, p. 13-15, maio 2013.

KAIRALlA, V.; FRANCISCO, C. D. (Prod.) Meninos de Rosa, Meninas de Azul (Homofobia e Bullying Homofóbico) (Documentário). Faculdades Integradas Alcântara Machado - FIAM, Jornalismo, II semestre, 2012. Disponível em: https://www.youtube.com/ watch?v=14RW6BKJydQ Acesso em: 30 de outubro de 2014.

LEITE, L. Quando a invisibilidade pode proteger - mas também oprimir: histórias de refúgio no Brasil, baseados na orientação sexual ou na identidade de gênero. In: Caritas Arquidiocesana de São Paulo (CASP); Alto Comissariado das Nações Unidas (ACNUR) - no prelo, 2013. 
PIOVESAN, F. Direitos Humanos e o Direito Constitucional Internacional. São Paulo: Saraiva, 2012.

RAMOS, A. Asilo e Refúgio: semelhanças, diferenças e perspectivas. In: RAMOS, A; RODRIGUEZ, G.; ALMEIDA, G. (orgs.). 60 Anos de ACNUR: perspectivas de futuro. São Paulo: CLA editora, 2011a, p. 15-44.

RICCEUR, P. Etapa atual do pensamento sobre a intolerância. In: Academia Universal das Culturas. A Intolerância. Rio de Janeiro: Bertrand Brasil, 2000, p. 20-23.

SCHMITT, A.; SOFER, J. Sexuality and Eroticism Among Males in Moslem Societies. Binghamton: Harrington Park Press, 1992. In: ILGA. A world survey of laws: Criminalisation, protection and recognition of same-sex love. 2014.

STEELE, B.; EDWARDS, K.; STOURTON, F. Hunted: the war against gays in Russia. (Documentário). HBO Documentary Films, 2014.

\title{
RESUMO
}

O presente artigo tem como objetivo analisar a situação de intolerância sofrida pelos refugiados LGBTI no Brasil, primeiro por serem refugiados e, segundo pela própria orientação sexual. Apesar do avanço dos Direitos Humanos nas últimas décadas, ainda há situações de violações dos Direitos Humanos em diversos países, especialmente naqueles em que ser homossexual é crime, muitas vezes, punido com a pena de morte. Quando essas pessoas chegam ao Brasil, encontram muitas dificuldades e constatam a inexistência de diálogo, discussão e políticas públicas concretas para que refugiados LGBTI tenham seus direitos respeitados.

Palavras chave: Refugiados LGBTI, Intolerância, Direitos Humanos.

\begin{abstract}
The current article aims to analyse intolerance experienced by LGBTI refugee living in Brazil, first, for being refugees and, second, for their own sexual orientation. Although circumstances surrounding Human Rights have progressed in the last few decades, violations of Human Rights are still at large especially in those countries where homosexuality is considered as an indictable offense. Some countries practice death penalty to this day. After arriving in Brazil as refugees they still face difficulties. More dialogues, discussion and concrete public policy are necessary to safeguard their rights and needs.
\end{abstract}

Keywords: LGBTI Refugee, Intolerance, Human Rights. 
